\title{
Impact of Sprout Management on Growth, Quality and Yield of Pointed Gourd (Trichosanthes dioica Roxb.)
}

\author{
Kanchan Kumari Gupta ${ }^{1}$, Nayanmoni Buragohain ${ }^{1 *}$, B. P. Gautam ${ }^{1}$, \\ S. Langthasa ${ }^{1}$, R. K. Goswami ${ }^{2}$ and M. K. Kalita ${ }^{3}$ \\ ${ }^{1}$ Department of Horticulture, ${ }^{2}$ Department of Crop Physiology, ${ }^{3}$ Department of Plant \\ Pathology, Biswanath College of Agriculture, Assam Agricultural University, Biswanath \\ Chariali-784176, Assam, India \\ *Corresponding author
}

\begin{tabular}{|l|}
\hline Ke y w o r d s \\
Pointed gourd, \\
Sprout \\
management, \\
Growth, Quality, \\
Yield
\end{tabular}

\section{Introduction}

Pointed gourd (Trichosanthes dioica Roxb.) is one of the most popular vegetables due to its higher nutritional and medicinal properties, unique taste and easy digestibility. It is known by the names Parwal, Potal, Parmal, wild snake gourd and Green Potato. It is a perennial 
crop and due to availability for eight months in a year it is highly accepted by the growers. The Bengal -Assam region is considered to be the primary center of origin. In India, total area under pointed gourd cultivation is 20 thousand hectare with an annual production of 325 thousand tones (Anon., 2019). It is cultivated extensively in Assam, West Bengal, Bihar, Uttar Pradesh, Odisha, Maharashtra and Gujrat.

The unripe immature fruits as well as young leaves are used as vegetable, the leaves and tender stems of vine are used in soup preparation and also the young shoot tips are consumed by some parts of the country. Being known as "King of gourds" it is rich in nutrients and the fruit is good for curing heart and brain disorder, has diuretic and laxative properties and is also cardio tonic. It is recommended against bronchitis, biliousness, high fever and nervousness.

It controls blood cholesterol and sugar and act as blood purifier. Since pointed gourd is a dioeciously cucurbit, normally propagation is done by identifying male and female tuberous root of the previous season. A number of vines are produced from the root sucker and if these are allowed to grow as such, it may lead to imbalance between vegetative and reproductive growth, alteration in $\mathrm{C}$ : $\mathrm{N}$ ratio resulting in reduction in productivity. Adoption of pruning technique in order to maintain the required number of vines per plant may be one of the fruitful cultural approaches for boosting up the productivity in pointed gourd.

Although it needs extra cost, the practice could increase the economic return by increasing yield and improvement of the quality of the fruits (Davis and Ester, 1993).The fruit development can be controlled by pruning the plants into one, two, three and four vines to obtain proper balance between fruit number and fruit size. Since, no systematic study was conducted on these aspect an experiment was planned to standardize the optimum number of vines for better growth, yield and fruit quality of pointed gourd at different pruning levels under north bank plains of Assam.

\section{Materials and Methods}

The present experiment was carried out at Instructional cum Research Farm, Department of Horticulture, Biswanath College of Agriculture, Assam Agricultural University during kharif season of 2018. The soil of the experimental plot was well drained and acidic (5.35) with good water holding capacity. A recommended dose of $80 \mathrm{~kg} \mathrm{~N}$ (as Urea), 50 $\mathrm{kg} \mathrm{P}_{2} \mathrm{O}_{5}$ (as SSP) and $50 \mathrm{~kg} \mathrm{~K}_{2} \mathrm{O}$ (as MOP) along with FYM@20 t per hectare were applied at the time of final land preparation. Urea (2\%) and MOP (2\%) were applied as foliar spray at 2 months interval. The experiments comprised of five pruning treatments viz. retention of one sprout, retention of two sprouts, retention of three sprouts, retention of four sprouts and control(without pruning) of same cultivar of pointed gourd(local) which was laid out in randomized block design with four replications.

The fruits of this cultivar are small, $5-8 \mathrm{~cm}$ long, tapering at the ends, green in colour and striped. Root suckers of $10-12 \mathrm{~cm}$ long were planted in pits of size $45 \mathrm{~cm}$ x $45 \mathrm{~cm} \mathrm{x} 45 \mathrm{~cm}$ prepared at a spacing of $2.0 \mathrm{~m} \times 2.0 \mathrm{~m}$. The experimental plots were mulched with paddy straw. Pruning was done in weekly interval starting from one month after planting using sharp knife. For single sprout all other sprouts were removed leaving only one sprout to grow, for two sprouts only two sprouts were retained and all others were removed and the similar was done for three and four sprouts. 
Three plants were selected in each plot to take observation on vegetative growth, fruit yield and quality out of six plants planted (five female and one male).

\section{Statistical analysis}

Observation made during field experimentation and data obtained from laboratory determinations were subjected to analysis of variance and t-test by Randomized Block Design (RBD).Significance or nonsignificance of the variance due to treatments was determined by calculating the respective ' $F$ ' values by following the method described by Panse and Sukhatme (1985).The significance of difference between mean values of the character of the treatment was tested by computing critical difference.

\section{Results and Discussion}

\section{Effect of pruning on plant growth}

Growth characters of pointed gourd were significantly influenced by the different pruning treatments.(Table1).Maximum vine length $(195.47 \mathrm{~cm}$ and $384.95 \mathrm{~cm})$, intermodal length $(9.55 \mathrm{~cm}$ and $12.21 \mathrm{~cm})$, leaf number per vine (170.33 and 206.91) and leaf area per vine $\left(5491.36 \mathrm{~cm}^{2}\right.$ and $\left.6670.78 \mathrm{~cm}^{2}\right)$ at 90 DAP and 120 DAP was observed in plants with three sprouts while minimum was recorded in plants without pruning.

Increase in vine length and intermodal length with advancement of plant age might be due to increase in growth and development of the plants along with more availability of nutrients, water and light to plants (Paksoy and Akella, 1993). The increased vine length is a result of rapid elongation of internodes by both cell division and cell elongation (Krishnamoorthy,2002). Preece and Read (2005) observed that pruning limited the vegetative growth and allowed more light penetration, so increased plant height, stem diameter and fruit length as compared to plants without pruning. Higher number of leaves per vine is due to exposure of the plants to direct sunlight and precipitation, enough free space for growth and better air movement. Nimje et al., (1990) also recorded similar findings in tomato.

Increase in leaf area might be due to increased water supply for which the plants were able to synthesize more efficiently and resulted in increasing shoot length and plant height (Singh, 1989). Maximum number of lateral branches (5.89 and 8.00) at 90 and 120 DAP was recorded in plants with single sprout while minimum was in plants with no pruning.

This might be due to larger area for free growth was provided by single sprout compared to other treatment. However, significant variation of petiole length was found only at 120 DAP with highest petiole length $(4.37 \mathrm{~cm})$ in plants with three sprouts and minimum was observed in treatment with no pruning. The improvement of morphological parameters of pointed gourd in plants with three sprouts might be due to better competition of plants for water, nutrient and light (Alsadon et al., 2013).

Growth parameters like days to first flower initiation was not influenced by the different pruning treatments on pointed gourd (Table 2). However, duration from fruit set to harvest, days to harvest and total crop duration was significantly influenced by the treatments. Minimum number of days from fruit set to harvest (10.50) and days to first harvest (106.18) were taken by single sprouted plants.

On the other hand plants without pruning took maximum number of days for these parameters.

The difference in the treatments might be due 
to better exposure of fruits to light and better aeration in single sprouted plants and pruning facilitated more leaf expansion and thereby could harness more solar energy from a relatively larger area. Pruning in general enhances fruit size and earliness (Mnzava, 1984).

Alam et al., (2016) and Yadav et al., (2017) found significantly lower number of days required for first harvesting in single stem tomato compared to plants without pruning. Duration of the crop greatly influences the yield and productivity of the crop.

Prolonged harvest duration is an important aspect to catch the early market and to ensure maximum returns (Sharma, 2016).

The total crop duration was maximum in plants maintaining three sprouts (205.42 days) followed by plants with two sprouts(202.47 days) and minimum (198.27 days) was recorded in single sprouted plants. This might be due to super morpho-physiological characters of three stem plant.

Effect of pruning on yield and yield attributing characters

Different pruning treatments significantly influenced the yield attributes and yield of pointed gourd (Table 3). Maximum number of female flowers (238.50) and fruits (225.58) per plant, highest fruit yield $(4.21 \mathrm{~kg} /$ plant $)$ and total yield $(8.77 \mathrm{t} / \mathrm{ha})$ was recorded in plants with three sprouts while single sprouted plants produced minimum number of female flowers (152.25), fruits (133.75), lowest fruit yield $(2.03 \mathrm{~kg} / \mathrm{plant})$ and total yield (4.22 t/ha).

Higher leaf area due to pruning treatment might be contributing more accumulation of photosynthates resulting in production of more primary branches leading to higher number of flowers per vine. Longest vine length in plants retaining three stems might be the reason for more number of fruits per plant, yield per plant (kg) and yield per ha (tones). Singh (2004)reported a positive correlation between vine length and yield in Chow-chow. Initiation of vegetative growth enhances assimilate transport to either root or fruit (Arzani et al., 2009) and pruning system also keeps a balance in source/sink relationship and $\mathrm{C} / \mathrm{N}$ ratio (Franco et al., 2009). Akand et al., (2014) and Mazed et al., (2015) reported that three stem pruning produced maximum fruits per plant and highest yield per plot while minimum was obtained in one stem pruning in tomato.

\section{Effect of pruning on quality parameters:}

A significant difference in quality parameters viz. ascorbic acid and vitamin A content was observed with different pruning treatments (Table 4). However, total soluble solid and flavonoid content remain non-significant. The highest ascorbic acid content $(15.84 \mathrm{mg} / 100 \mathrm{~g})$ was observed in treatment maintaining one sprout while vitamin A content (223.61 IU) was found higher in the plants maintaining three sprouts and the lowest value for both ascorbic acid and vitamin A content was found in plants with no pruning.

The variation in ascorbic acid content between the pruning treatments might be due to the positive effect of pruning on ascorbic acid content attributing limited vegetative growth and more light penetration to improve photosynthetic efficiency and thus lead to more ascorbic acid content as light is the major factor affecting ascorbic acid.

Results of the present study showed pointed gourd plants maintaining three sprouts is the best treatment for maximizing the production of pointed gourd without affecting its quality under the agro -climatic condition of Assam. 
Table.1 Effect of pruning on plant growth parameters of pointed gourd

\begin{tabular}{|c|c|c|c|c|c|c|c|c|c|c|c|c|}
\hline \multirow[t]{2}{*}{ Treatments } & \multicolumn{2}{|c|}{ Vine length(cm) } & \multicolumn{2}{|c|}{$\begin{array}{l}\text { Internodal } \\
\text { length }(\mathrm{cm})\end{array}$} & \multicolumn{2}{|c|}{ Leaves(no./vine) } & \multicolumn{2}{|c|}{ Leaf area $\left(\mathrm{cm}^{2} /\right.$ vine } & \multicolumn{2}{|c|}{$\begin{array}{l}\text { Lateral } \\
\text { branches } \\
\text { (no./vine) }\end{array}$} & \multicolumn{2}{|c|}{$\begin{array}{l}\text { Petiole length } \\
\text { (cm) }\end{array}$} \\
\hline & $\begin{array}{l}90 \\
\mathrm{DAP} *\end{array}$ & $\begin{array}{l}120 \\
\text { DAP }\end{array}$ & $\begin{array}{l}90 \\
\text { DAP }\end{array}$ & $\begin{array}{l}120 \\
\text { DAP }\end{array}$ & $\begin{array}{l}90 \\
\text { DAP }\end{array}$ & $\begin{array}{l}120 \\
\text { DAP }\end{array}$ & $\begin{array}{l}90 \\
\text { DAP }\end{array}$ & $\begin{array}{l}120 \\
\text { DAP }\end{array}$ & $\begin{array}{l}90 \\
\text { DAP }\end{array}$ & $\begin{array}{l}120 \\
\text { DAP }\end{array}$ & $\begin{array}{l}90 \\
\text { DAP }\end{array}$ & $\begin{array}{l}120 \\
\text { DAP }\end{array}$ \\
\hline $\begin{array}{l}\text { Retention of one } \\
\text { sprout }\end{array}$ & 182.89 & 367.85 & 7.73 & 10.00 & 160.65 & 193.70 & 4114.18 & 4960.66 & 5.89 & 8.00 & 2.07 & 3.25 \\
\hline $\begin{array}{l}\text { Retention of two } \\
\text { sprouts }\end{array}$ & 187.27 & 371.38 & 8.063 & 10.45 & 163.72 & 198.06 & 4877.44 & 5900.21 & 5.84 & 7.33 & 2.69 & 3.42 \\
\hline $\begin{array}{l}\text { Retention of } \\
\text { three sprouts }\end{array}$ & 195.47 & 384.95 & 9.55 & 12.21 & 170.33 & 206.91 & 5491.36 & 6670.78 & 5.83 & 6.60 & 2.92 & 4.37 \\
\hline $\begin{array}{l}\text { Retention of four } \\
\text { sprouts }\end{array}$ & 179.01 & 357.13 & 7.49 & 9.62 & 157.15 & 188.45 & 3876.77 & 4648.94 & 5.77 & 6.19 & 2.71 & 4.01 \\
\hline Without pruning & 169.79 & 342.63 & 7.05 & 8.62 & 151.45 & 181.39 & 3433.31 & 4098.62 & 5.49 & 6.13 & 2.79 & 3.77 \\
\hline Mean & 182.89 & 364.79 & 7.98 & 10.18 & 160.66 & 193.70 & 4358.61 & 5255.84 & 5.77 & 6.85 & 2.63 & 3.76 \\
\hline $\operatorname{S.Ed}( \pm)$ & 1.41 & 4.23 & 0.39 & 0.59 & 0.975 & 1.48 & 33.49 & 61.15 & 0.076 & 0.50 & 0.31 & 3.76 \\
\hline C.D.(0.05) & 3.11 & 9.32 & 0.86 & 1.32 & 2.15 & 3.25 & 73.77 & 134.72 & 0.17 & 1.10 & $\mathrm{NS} * *$ & 0.156 \\
\hline
\end{tabular}

*Days after planting, ** Non significant 
Table.2 Effect of pruning on growth parameters of pointed gourd

\begin{tabular}{|c|c|c|c|c|}
\hline Treatments & $\begin{array}{c}\text { First flower } \\
\text { initiation(days) }\end{array}$ & $\begin{array}{c}\text { Duration from } \\
\text { fruit set to } \\
\text { harvest (days) }\end{array}$ & $\begin{array}{c}\text { Days to first } \\
\text { harvest }\end{array}$ & $\begin{array}{c}\text { Total duration } \\
\text { (days) }\end{array}$ \\
\hline Retention of one sprout & 79.75 & 10.50 & 106.18 & 198.27 \\
\hline Retention of two sprouts & 81.50 & 11.25 & 117.20 & 202.47 \\
\hline Retention of three sprouts & 85.75 & 12.00 & 119.32 & 205.42 \\
\hline Retention of four sprouts & 86.25 & 12.25 & 120.33 & 200.68 \\
\hline Without pruning & 88.75 & 12.50 & 123.55 & 199.00 \\
\hline Mean & 84.40 & 11.70 & 117.32 & 201.17 \\
\hline S.Ed( \pm C.D.(0.05) & 7.90 & 0.35 & 0.24 & 2.06 \\
\hline & NS & 0.76 & 0.54 & 4.53 \\
\hline
\end{tabular}

Table.3 Effect of pruning on yield attributes and yields of pointed gourd

\begin{tabular}{|l|l|l|l|l|}
\hline Treatments & $\begin{array}{l}\text { Female flowers } \\
\text { (no./plant) }\end{array}$ & $\begin{array}{l}\text { Fruits } \\
\text { (no./plant) }\end{array}$ & Yield (kg/plant) & Yield(t/ha) \\
\hline Retention of one sprout & 152.25 & 133.75 & 2.03 & 4.22 \\
\hline Retention of two sprouts & 207.75 & 195.24 & 3.99 & 8.31 \\
\hline Retention of three sprouts & 238.50 & 225.58 & 4.21 & 8.77 \\
\hline Retention of four sprouts & 185.81 & 166.38 & 3.77 & 7.85 \\
\hline Without pruning & 181.38 & 166.25 & 2.65 & 5.50 \\
\hline Mean & 193.14 & 174.44 & 3.33 & 6.93 \\
\hline S.Ed( $(\mathbf{)}$ & 13.30 & 12.57 & 0.14 & 0.42 \\
\hline C.D.(0.05) & 29.31 & 27.68 & 0.31 & 0.92 \\
\hline
\end{tabular}

Table.4 Effect of pruning on quality parameters of pointed gourd

\begin{tabular}{|l|c|c|c|c|}
\hline Treatments & $\begin{array}{c}\text { Ascorbic acid } \\
(\mathbf{m g} / \mathbf{1 0 0 g})\end{array}$ & $\begin{array}{c}\text { Vitamin } \\
\text { A(IU) }\end{array}$ & TSS $\left({ }^{\mathbf{0}}\right.$ Brix $)$ & $\begin{array}{c}\text { Flavonoid } \\
(\mathbf{\%} \mathbf{g})\end{array}$ \\
\hline Retention of one sprout & 15.84 & 223.09 & 2.87 & 0.17 \\
\hline Retention of two sprouts & 15.79 & 223.18 & 2.78 & 0.15 \\
\hline Retention of three sprouts & 15.80 & 223.61 & 2.84 & 0.24 \\
\hline Retention of four sprouts & 15.77 & 223.03 & 2.76 & 0.16 \\
\hline Without pruning & 15.65 & 222.14 & 2.76 & 0.24 \\
\hline Mean & 15.77 & 223.01 & 2.80 & 0.19 \\
\hline S.Ed( $\mathbf{(})$ & 0.04 & 0.25 & 0.14 & 0.021 \\
\hline C.D.(0.05) & 0.08 & 0.55 & NS & NS \\
\hline
\end{tabular}




\section{References}

Akand, Md. H., Mazed, H.E.M.K., Haque, Md. N., Partho,S.G. and Islam Pulok,Md.A.2014. Effect of potassium and stem pruning pruning on growth and yield of tomato (Lycopersicon esculentum Mill.) Int. Multidiscip. J., 3(12): 30-43.

Alam, M.S.,Islam,N., Ahmad,S., Hussen, M.I. and Islam, M.R. 2016. Effect of different staking methods and stem pruning on yield and quality of summer tomato. Bangladesh J. of Agri. Res., 41(3): 419-432.

Alsadon, A., Mahmoud, W.A., Hesham, A.R. and Abdullah, I. 2013. Effect of pruning system on growth,fruit yield and quality trait of three green house grown bell pepper (Capsicum annum L.) cultivars. Australlian J. Crop Sci., 7(9): 13091316.

Anonymous 2019. Area and production of Horticultural crop :All India Agricoop. nic. in. Browsed on $4^{\text {th }}$ July, 2019.

Arzani, K., Bahadori, F. and Piri, S. 2009. Paclobutrazol reduces vegetative growth and enhances flowering and fruiting of mature 'J.H. Hale' and 'Red Skin' trees. Hort. Environ. and Biotech., 50(2):84-93.

Davis, J.M. and Ester, E.A. 1993. Spacing and pruning effect on growth and yield and economic return of staked fresh market tomatoes. J.Soc. Hort..Sci. 118(6):719-725.

Franco, J.L., Diaz, M.,Dianez, F. and Camacho, F. 2009. Influence of different type of pruning on cherry tomato fruit production and quality. $J$. Food Agri. Environ., 7(3-4): 248-253.

Krishnamoorthy, H.N. and Sandooja, J.K.2002. Effect of ethereal and gibberalic acid on growth flowering and sex expression of Cucurbita pepo. Haryana J. Hort. Sci., 10(3-4):249-252.
Mazed, K.H.E.M., Akand, Md. H., Haque, Md. N., Pulok,Md.A.I. and Partho, S.G. 2015. Yield and economic analysis of tomato (Lycopersicon esculentum Mill.) as influenced by potassium and stem pruning. Int. J. Scientific and Res. Publications, 5(1): 15 .

Mnzava, N.A. 1984. Influence of cluster and spacing on set,growth,yield and quality of early fruit of the West Virginia 63 tomato (Lycopersicon esculentum Mill.).Dissertation for award of M.Sc. Degree at Sokoine University of Agriculture,Morogoro Tanzania. p.54.

Nimje, P.M., Wajnam, O.D. and Shyam, M. 1990. Green house technology for vegetable production. Proceedings of XI International Congress on the use of plastics in Agriculture.pp.83-90.

Paksoy, M. and Akella, M.1993. The effects of different prunings on the yield and quality of eggplant cultivars grown in green house conditions. $2^{\text {nd }}$ Symp. of Prot.Cultiv. of Solanacea in Mild winter climates, Turkey, p.366.

Panse,V.G. and Sukhatme, P.V. 1985. Statistical methods for agricultural workers, $4^{\text {th }}$ Edn., ICAR, New Delhi.

Preece, J.E. and Read, P.E.2005. The Biology of Horticulture. $2^{\text {nd }} \mathrm{Ed}$. Copyright by John Wiley and Sons.New York, United States, pp 528.

Sharma, D.2016. Effect of spacing and training system on productivity of hybrid cucumber under naturally venyillated polyhouse.M.Sc.(Agri.) Thesis. Himachal Pradesh Krishi Vishvavidyalaya, Palampur, Himachal Pradesh, India.

Singh, K. 1989. Pointed gourd (Trichosanthes dioica Roxb.) Indian Horticulture, 33 $\& 34$.

Singh, R.K. 2004. Correlation and path coefficient studies in Chow-Chow (Sechium edule). Indian J. Horticulture, 61(2):154-157. 
Yadav, S., Ameta, K.D., Sharma,S.K., Dubey, R.B., Rathore, R.S., Kumar,H. and Kapuriya, V.K.2017. Effect of spacing and training on vegetative growth

characteristics and yield of tomato (Solanum lycopersicon L.) grown in polyhouse. Int. J. Curr. Microbiol. App. Sci., 6(5):1969-1976.

\section{How to cite this article:}

Kanchan Kumari Gupta, Nayanmoni Buragohain, B. P. Gautam, S. Langthasa, R.K. Goswami and Kalita M.K.2020. Impact of Sprout Management on Growth, Quality and Yield of Pointed Gourd (Trichosanthes dioica Roxb.). Int.J.Curr.Microbiol.App.Sci. 9(01): 1030-1037. doi: https://doi.org/10.20546/ijcmas.2020.901.115 